\title{
Teacher identity and Religion Education in Life Orientation
}

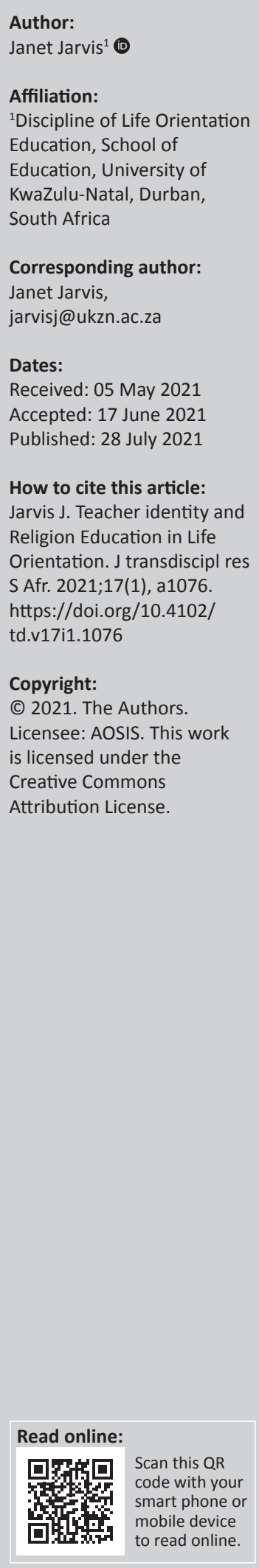

Integral to the Life Orientation curriculum is democracy and human right. This article contends that considering human rights cannot simply be a theoretical exercise as the implementation thereof affects lived human experience. Currently held narratives of lived experience need to be dialogically explored. Integrally linked to any such exploration is the identity of the explorer. It can be said that individuals are made to varying degrees by systems and networks of power in society, including dominant discourses. However, they also have the capacity, by exercising individual agency, to make themselves according to the way in which they respond to the intersections that shape identity, including ethnicity, culture, class, religion, gender, sexual orientation and so forth. This article seeks to explore teacher identity and, in particular, teacher religious identity, with a view to transformed Religion Education. The argument is made for Life Orientation teachers to negotiate their religious identity from a position of 'religious identity paralysis' or 'religious identity paradox' or even 'religious identity flexibility' to one of 'religious identity transformation'. Both in-service and pre-service teachers participated in the studies informing this article.

Keywords: classroom praxis; empathetic-reflective-dialogue; identity negotiation; religion education; religious identity transformation.

\section{Introduction}

Human rights issues are embedded in the teaching-learning of democratic values as outlined in the 'Manifesto of Values, Education and Democracy'. ${ }^{1}$ Included in the Curriculum and Assessment Policy Statement (CAPS) for Life Orientation (LO) (Grades 7-12) ${ }^{2}$ are the topics: Constitutional rights and responsibilities (Grades 7-9) and Democracy and Human Rights (Grades 10-12). The specific aims in both phases is to expose learners to their constitutional rights and responsibilities, to diversity in society, and to encourage respect for the rights of others. According to CAPS, it is anticipated that by exploring human rights, as embedded in the LO curriculum, learners will be developed who can contribute to a just and democratic society. This cannot, however, simply be a theoretical exercise. ${ }^{3}$ Human rights, or the implementation thereof, affects lived human experiences. Integrally linked to any exploration of the narratives of lived experience is the identity of the explorer. Identity needs to be considered in terms of a negotiation between master narratives and individual agency. It can be said that individuals are made to varying degrees by systems and networks of power in society, including dominant discourses. ${ }^{4}$ However, they also have the capacity to make themselves, to varying degrees, according to the way in which they respond to the intersections that shape identity, including ethnicity, culture, class, religion, gender, sexual orientation, and so forth.

This article seeks to explore teacher identity, in particular, in relation to the human right to freedom of religion, with a focus on Religion Education (RE), located within the LO curriculum. This has implications for classroom practice. The right to freedom of religion is embedded in the United Nation's Declaration on the Elimination of all forms of Intolerance and of Discrimination based on religion or belief (1981). In South Africa, this finds expression in the South African Constitution and more specifically, the Bill of Rights. ${ }^{5}$ The latter gives every individual the freedom to adhere to a particular religion or to refrain from adhering to a specific religion. The South African Religion and Education Policy ${ }^{6}$ gives expression to this in the schooling arena. This Policy ${ }^{6}$ assumes that teachers will simply and seamlessly adopt a multi-religious approach to RE. Prior to 1994, Christian National Education (CNE) and the specific brand of Christianity that was endorsed by the same was entrenched in the South African school curriculum. A mono-religious approach to teaching RE was prescribed. Post 1994, teachers were expected to depart from this 
mould of mono-religious indoctrination. For many teachers, moving from a mono-religious Christian approach to a multireligious approach required a paradigm shift, with which they struggled, resulting in something of a religious identity conflict. This conflict arose, in the main, as many teachers considered exploring religions other than their own, as compromising. It is probable that if a teacher feels that specific content in the LO curriculum compromises his or her personal beliefs, then that section of the curriculum may well be disregarded or altered. ${ }^{7}$ For the purposes of this article, the LO teacher, responsible for teaching RE as part of the $\mathrm{LO}$ curriculum, will be referred to as the RE teacher.

The findings that support the arguments for unpacking the religious identity of the RE teacher are drawn largely from two localised research projects ${ }^{8,9}$ undertaken by the author in 2008 and 2012. These projects were located within two largescale international projects facilitated by HREiD in (2004-2008 and 2009-2012). ${ }^{10,11}$ HREiD is a South African research group established in 2000, focusing on human rights and Human Rights Education in multicultural societies. The author's 2008 study, ${ }^{8}$ focused specifically on the identity and voice of the in-service RE teacher and how these influence approaches to RE. The participants in the author's 2012 study $^{9}$ were preservice RE teachers in a South African Higher Education Institution.

\section{Research design and methodology}

Both the above-mentioned 2008 and 2012 studies were located within an interpretive paradigm, adopting an exploratory case study approach. In both the cases, participants completed self-administered questionnaires in which they expressed their understanding of religious freedom. They also described how they thought their biography influenced their approach to RE. Responses to the questionnaire were further probed in semi-structured focus group interviews. The in-service participants (2008) taught RE in purposively selected KwaZulu-Natal primary schools. ${ }^{9,10}$ The schools represented three different school contexts in terms of demographics and resources. Male and female teachers, young and fairly inexperienced teachers as well as older, more experienced teachers, representative of all race groups, participated in the study. The pre-service teachers in the 2012 study were male and female students in their final year of their Bachelor of Education degree, with LO as one of their teaching specialisations. They would be teaching in schools the following year. The participants in both the 2008 and 2012 studies completed consent forms. Ethical clearance was obtained from the relevant gatekeepers. In keeping with the assurance of anonymity, pseudonyms are used in this article when referring to the participants.

The data collected in both studies were analysed thematically with the following themes emerging: (1) religious identity paralysis/paradox; (2) religious identity flexibility; and (3) religious identity transformation. The following framework provided the lens through which the data was viewed,

\section{Theoretical framework: Religious identity formation}

Social identity theory explores the relationship between the individual and society, and is crucial to understanding how identity is constructed and experienced. The aligned notions of 'multiple identities', ${ }^{12}$ possible identity conflict, ${ }^{13}$ and 'identity negotiation' ${ }^{\prime 4,15}$ are helpful in exploring how teachers construct their religious identity. The process of socialisation and the shaping of particular identities by dominant social discourses begins from birth. ${ }^{16}$ However, identities are not fixed but multi-faceted and dynamic, capable of deconstruction and reconstruction. ${ }^{17}$ This underpins the notion that through a process of identity negotiation it is possible for individuals to move from a previous held, seemingly fixed identity, to that of a transformed identity. Successful identity exchanges can lead to increased identity capital. ${ }^{18}$ This identity capital refers to the set of strengths that individuals have when constructing and framing their identity ${ }_{1}^{18}$ in this case, religious identity in their professional context. This can lead to religious identity transformation and contribute to the RE teacher's professional capital. ${ }^{19}$

\section{Findings and discussion}

The participating teacher's biographies strongly influenced the way in which they either promoted or discouraged an inclusive approach to RE in a context of religious diversity. ${ }^{8}$ However, the way in which they managed their identities differed from teacher to teacher. Teachers identifying with a particular religion that is more exclusive in nature, struggled the most. ${ }^{8,20}$ They were fearful of possibly compromising their own beliefs by teaching about religions other than their own. Teachers were called on to consider negotiating their religious identity by moving from a position of 'identity paralysis' or 'identity paradox' or even 'identity flexibility' to one of 'identity transformation'.

\section{Religious identity paralysis and paradox}

Teachers experiencing religious identity paralysis or a bounded identity, ${ }^{21,22}$ were so tied to their membership of certain social categories that they elected to disregard any religion other than that to which they subscribed. They preferred to teach adopting a mono-religious approach that promoted their particular religion.

Religious identity paradox refers to those teachers that experienced discomfort at the fact that religions other than that promoted by the previously dominant CNE dispensation, were being marginalised. While they felt bounded by their own religious identities (in most cases, Christianity), they recognised the need to be more inclusive. However, it became apparent that for many teachers this was difficult and they were not able to make the transition.

Thelma (an in-service teacher participant in the 2008 study) provided an example of this religious identity paralysis. She 
completed her teacher training during the years of Apartheid and $\mathrm{CNE}$, before the new democracy which came into being in 1994. She is a devout Christian and her church teaches that only Christianity should be spoken about in the classroom and no other religion should be mentioned. In the primary school to which she was posted, she found it extremely difficult to teach RE, adopting anything other than a monoreligious approach that promoted Christianity. With the passing of time, however, she became increasingly uncomfortable as more children representing a variety of religions were accepted into the school and she realised that she was marginalising them and their beliefs. She was, however, at the time of the study, unable to change her approach. ${ }^{8}$

The pre-service teachers that experienced religious identity paralysis expressed themselves as follows:

'Not everyone is open-minded and believe[s] in other religions ... I believe the religion I follow is the best and that's the only God that exists'. (Maya, female, pre-service teacher.)

'In my belief I am supposed to promote only Islam. That is the basic requirement for any Muslim. How can I go against that? It will go against everything I believe in'. (Farida, female, preservice teacher)

Julie, a committed Christian, believes that her religion is right. She expressed an identity paradox, explaining that while she believes that there is only one truth or way, she, nevertheless, could never force her belief on others because that would be discriminatory. ${ }^{9}$

Teachers experiencing religious identity paralysis or paradox, and who are unable to meaningfully negotiate their religious identity were ineffective in addressing religion within a human rights framework. They were unable to promote the human right to religious freedom.

\section{Religious identity flexibility}

Those teachers who were able to express a measure of individual agency adopted a position of religious identity flexibility. They were able to remain committed to their own religious identity while still adopting a multi-religious approach to RE. These teachers were happy to teach about different religions and to promote religious literacies. RE was taught in a way that was most often technicist, without any meaningful engagement taking place.

Sarisha, who qualified post-1994, provides an example of a teacher who exercised religious identity flexibility. She adopted a multi-religious approach to RE, preparing her lessons well, so that every faith represented in the classroom was featured in her lessons. Her religious literacy was excellent as she had, for example, made it her goal to know the names and traditions of various religious festivals. While her lessons provided knowledge, the learners were, however, still taught about different religions in a way that included 'othering'. There was reference made to what they (the other) believe, when referring to learners who adhered to a religion other than her own. While seemingly accepting of religions other than her own, she continued to other those who believed differently. There was no meaningful dialogical engagement. ${ }^{8}$

In the study conducted with the pre-service teachers ${ }^{9}$ the following responses speak to religious identity flexibility:

'Every individual or religious group should be free and do what their religious group says. They should follow their own principles which are being said by their God'. (Nosipho, Female, pre-service teacher)

'Everyone has the right to speak about what they believe, and should not be threatened. Learning from views and practices of other religions does not mean one would stay away from their own religion'. (Jabu, Female, pre-service teacher)

'I will be able to facilitate Religion Education because I am not compromising my salvation, but merely educating learners about the different religions of the world and South Africa'. (Ncami, Female, pre-service teacher)

These pre-service teachers were satisfied to simply know about religions other their own. They were content to adopt an inclusive, multi-religious approach to RE. By doing so, however, they would not necessarily engage with substantial issues, including prejudice, suspicion, fear and stereotyping that often underpin the way in which adherents of different religions regard one another, not least in the RE classroom.

\section{Religious identity transformation}

Teachers are expected to manage multiple identities as they move in and out of their personal, social and professional domains. This includes their religious community and school classroom. Religious identity conflict between their personal and professional identities, calls for identity negotiation. ${ }^{14,15}$ The teacher negotiating his or her religious identity, would need to put into parenthesis his or her own values and beliefs, while not necessarily undermining them. ${ }^{8,20,23}$

Martha who exercised religious identity transformation, expressed herself as following:

'My belief is firm and I feel very secure therefore there is no problem to teach religious freedom in schools. I can deepen the learners' faith and belief in their own religions, at the same time teaching them to respect other religions'. (Martha, female, inservice teacher)

She was able to put her religion into parenthesis, while meaningfully engaging with religions other than her own and encouraging her learners to do the same. ${ }^{8}$ Rather than teaching about religion, she was able to facilitate rich dialogical engagement which could be transformative, in promoting the human right to religious freedom. Her dialogical approach signalled the shift from classroom practice to classroom praxis, which is both reflective (thinking through something and not just taking it on face value) and reflexive in nature. In particular, reflexivity, or the consideration of the practical implications for possible change, informed new attitudes and practices. ${ }^{24,25}$ Encouraging classroom praxis serves the education agenda 
in South Africa of decolonising the curriculum. While classroom practice supports a very technicist approach to teaching, classroom praxis welcomes dialogue in the classroom where different voices can respectfully be heard and where discrimination, in this case, on the basis of religion, can be addressed. Martha's approach contributed to her professional capital. ${ }^{19}$

\section{Religion Education teacher's voice}

In order for true transformation to take place, RE teachers should be able to exercise their voice ${ }^{26}$ which can have a very practical, emancipatory dimension. This agency (or freedom to use their voice) translates into creating new ways of selfunderstanding, new forms of behaviour, and new codes of meaning with regard to religion. ${ }^{27}$ These teachers could play a pivotal role in supporting human rights values by promoting respect for those who believe differently.

Dialogical voice, ${ }^{28}$ in particular, is about searching for meaning and understanding. It has the potential to be emancipatory and transformational for those involved..$^{28}$ Dialogue takes place initially as self-dialogue in the individual's society-ofmind..$^{29}$ This is then articulated publicly as RE teachers expressing their opinions and considering the ideas of others. Dialogical engagement provides the opportunity to get to know oneself better. It also provides the opportunity to listen to others and to better understand those who believe differently to oneself. A threefold approach to dialogue has been suggested by Ipgrave. ${ }^{30}$ She refers to primary, secondary and tertiary dialogue. Whilst primary dialogue includes the acceptance of diversity, difference and change, secondary dialogue involves being open to difference. In addition, it includes a willingness to engage with difference and a readiness to learn from others. The actual verbal exchange would constitute the tertiary aspect of dialogue. Teachers who are able to employ an 'empathetic-reflective-dialogical' approach $^{31}$ recognise that each person has something of value to offer and they open up and encourage the possibility of learning from the other. ${ }^{30,32}$ They do so by entertaining understandings and questions from a diversity of religious traditions and perspectives. By promoting dialogical activity, teachers create the space for individual religious thinking, for intra-religious dialogue and inter-religious dialogue. Intrareligious dialogue allows for a verbal exchange between individuals belonging to the same religion, whereas interreligious dialogue takes place between individuals adhering to different religious traditions. Simply knowing about different religions (religious literacies) does not support a human rights agenda. A reciprocal understanding is helpful in influencing attitudes towards learners from a variety of religious and cultural backgrounds. ${ }^{33,10}$

Narrative unity ${ }^{34}$ takes place when, in this case, in-service or pre-service teachers meet each other simply as individuals and not as representatives of one religion or another. They put their own beliefs into parenthesis. ${ }^{23}$ They do so in the interests of adopting an impartial yet empathetic approach to the beliefs of others.

\section{Classroom praxis}

The teacher with a transformed religious identity ${ }^{8}$ is secure enough in his or her religious identity and religious discourse so as to be able to empathetically explore the practice and traditions of diverse religions represented in his or her classroom. He or she is less fearful of compromising his or her own religious position and equipped to engage in emancipatory discourse. ${ }^{32}$ By employing an empatheticreflective-dialogical voice, this teacher is able to create a classroom space for respectful, empathetic, reflective, dialogical engagement. ${ }^{35}$ This empathetic approach promotes the capacity to understand and respond to the religious experiences of another person with an increased awareness of that person's thoughts and feelings, and that these matter ${ }^{36,37}$ Learners should feel sufficiently secure in their own religious identity so as to engage with those who believe differently. By creating this space, teachers would be moving beyond mere classroom practice, by shaping a discourse that focuses on the issues surrounding RE as praxis in a religiously diverse school context. Classroom praxis could include an engagement with RE related topics of prejudice, stereotyping, fear and suspicion of the other.

Religion Education teachers employing an empatheticreflective-dialogical approach in contexts of religious diversity have the potential to select and employ more creative teaching methods and become agents of curriculum development and design.

\section{Role of higher education institutions}

This article advocates for the inclusion of an empatheticreflective-dialogical approach to teaching-learning in LO modules, in particular, those that prepare pre-service teachers to teach RE. Safe or non-threatening spaces, denoting the figurative and discursive use of the notion (Roux, 2012; Du Preez, 2013; Redmond, 2010; Stengel, 2010), $38,39,40,41$ could be created within LO modules for preservice teachers to interrogate their own religious biography and beliefs. This would include an exploration of the practices and traditions which influence those beliefs. Engaging in empathetic-reflection provides pre-service teachers with the opportunity to reflect on their attitudes towards those who hold beliefs that are different to their own. Recognising the individuality of religious thinking, the search for meaning and understanding ${ }^{28}$ is promoted by using a dialogical approach to share personal religious narratives. Each person is recognised as having 'something of value to contribute; it is opening $[u p]$ to the possibility of learning from the other'..$^{30(p .7)}$ Even amongst those that share a common religious identity, there could well be differences in interpretation and practice. Dialogical activity recognises the individuality of religious thinking and provides an opportunity to explore this.

This article argues that if pre-service teachers can be provided with the opportunity to successfully negotiate their religious identity, they could possibly be less fearful of compromising 
their own religious identity (often the root of religious identity paralysis or religious identity paradox) and more able to engage with confidence in situations of religious diversity. This process begins with the acceptance of diversity (religious identity flexibility). However, this needs to progress to a place of being open to diversity and willing to engage with difference and learn from others. When they have successfully negotiated their religious identity, the possibility exists that they will be able to employ an empathetic-reflective-dialogical approach in the RE classroom that will provide learners with safe spaces in which to express their own beliefs, as well as empathetically take into consideration the beliefs of other learners. It is at this point that meaning will be added to any multi-religious approach to RE as advocated by the Religion and Education Policy. ${ }^{6}$ The prototype RE teacher is the one who has undergone a process of religious identity negotiation and has experienced religious identity transformation.

\section{Conclusion}

As contended by Samuel and Stephens ${ }^{42}$ teachers:

[W]alk a tightrope in both developing a personal [religious] identity which sits comfortably with their own sense of self and maintaining a balance between satisfying the requirements of state and society and providing the source and impetus for change. (p. 478)

Pre-service teachers need to consider the juxtaposition between what is envisaged by the Religion and Education Policy ${ }^{6}$ and their personal religious identity. The interrelationship between these identities needs to be unpacked. For this exploration to be successful, space needs to be provided in initial Teacher Education LO modules for pre-service teachers to engage empathetically, reflectively and dialogically in respect of religious diversity. The religious identity of pre-service teachers can play a substantial role in either entrenching discrimination on the basis of religion or promoting empathetic, reflective religious dialogue. The teacher who has engaged in identity negotiation is equipped and empowered to pave the way to transformative teaching-learning of RE. It is through these teachers' classroom praxis that their learners will be encouraged to not only grow in their own religious beliefs, but also to empathetically respect the religious beliefs of others in society. By doing so, learners in our schools could be meaningfully equipped to participate in the religiously diverse tapestry that is South African society.

\section{Acknowledgements}

\section{Competing interests}

The author declares that she has no financial or personal relationship that may have inappropriately influenced her in writing this article.

\section{Author's contribution}

The author declares that she is the sole author of this research article.

\section{Ethical considerations}

Full approval for a period of 3 years was given by the University of KwaZulu-Natal, College of Humanities, Humanities and Social Sciences Research Ethics Committee, for research to be undertaken with consenting students in the area of human rights, and religious identity: HSS/0297/017.

\section{Funding information}

This research received no specific grant from any funding agency in the public, commercial or non-profit sectors.

\section{Data availability}

The author confirms that the data supporting the findings of this study are available within the article.

\section{Disclaimer}

The views and opinions expressed in this article are those of the author and do not necessarily reflect the official policy or position of any affiliated agency of the author.

\section{References}

1. Department of Education. Manifesto on values, democracy and education. Pretoria: Government Printers; 2001.

2. Department of Education. Curriculum and Assessment Policy Statement (CAPS). Pretoria: Government Printers; 2011.

3. Roux C. The 'Literacy Turn' in human rights and human rights education. In: Roux $C$, Becker A, editors. Human Rights Literacies. New York, NY: Springer; 2019; 3-30.

4. Foucault M. Power/Knowledge: Selected interviews and other writings, 1972-1977. New York, NY: Harvester Wheatsheaf; 1980.

5. South Africa. The Bill of Rights: Chapter 2 of the Constitution of the Republic of South Africa. Pretoria: Government Printers; 1996.

6. Department of Education. National Policy on Religion and Education. Pretoria: Government Printers; 2003.

7. Jarvis J. Reflections on Gender Identity in a Safe Space for Transforming Classroom Praxis. Journal for the Study of Religion. Special Edition. 2014; 27:169-191.

8. Jarvis J. The voice of the teacher in the context of religious freedom: A KwaZuluNatal case study [Unpublished Masters' dissertation]. Stellenbosch: Stellenbosch University; 2008.

9. Jarvis J. Paving the way to transformation: Student teacher's religious identity and Religion Education. Alternation Special Edition. 2013; 10:131-147.

10. Roux CD, Smith J, Ferguson R, Small R, Du Preez $P$, Jarvis J. Understanding human rights through different belief systems: Intercultural and interreligious dialogue. South African Netherlands Project on Alternative Developments (SANPAD). Stellenbosch: Stellenbosch University; 2006.

11. Roux C. Human Rights Education in diversity: Empowering girls in rural and metropolitan school environments [homepage on the Internet]. 2009. [cited 2011]. Available from: http://www.hreid.co.za

12. Giddens A. Modernity and self-identity: Self and society in the late modern age. Great Britain: TJ International Ltd.; 2002.

13. Jansen J. Image-ining teachers: Policy images and teacher identity in South African classrooms. S Afr J Educ. 2001; 21(4): 242-246.

14. Nias J. Reference groups in primary teaching: Talking, listening and identity. In: Ball S, Goodson I, editors. Teacher's lives and careers. London: Falmer Press; 1985; p. 105-119.

15. Nias J. Primary teachers talking: A study of teaching as work. London: Falmer Press; 1989.

16. Harro B. The cycle of socialisation. In: Adams M, Blumenfeld W, Castaneda $\mathrm{R}$, Hackman $\mathrm{H}$, Peters $M$, Zuniga $X$, editors. Readings for diversity and social justice. New York, NY: Routledge; 2000; p. 45-52.

17. Vandamme R. Teacher identity as a dialogical construction. In: Meijers $M$, Hermans $\mathrm{H}$, editors. The dialogical self theory in education: A multicultural perspective.: Springer; 2018; p. 111-128.

18. Côté J., Levine C. Identity formation, agency and culture: A social psychological synthesis. Mahwah, NJ: Lawrence Erlbaum Associates Publishing; 2002.

19. Hargreaves A, Fullan M. Professional capital: Transforming teaching in every school. New York, NY: Teachers College Press; 2012. 
20. Jarvis J. Teacher identity in a context of religious diversity. Alternation Special Edition. 2009;3:138-156

21. Featherstone F. Localism, globalism and cultural identity. In: Alcoff L, Mendieta E, editors. Identities: Race, class, gender and mationality. Malden: Blackwell Publishing; 2003; p. 342-359.

22. Gergen K. Relational being: Beyond self and community. Oxford: Oxford University Press; 2009

23. Jackson R. Religious education an interpretive approach. Great Britain: Hodder \& Stoughton Educational; 1997.

24. Roux C, Du Preez P. Clarifying students' perceptions of different belief systems and values: prerequisite for effective education praxis. S Afr J High Educ. 2006;30(2):514-531.

25. Quinlan O. The thinking teacher. Wales: Independent Thinking Press; 2014.

26. Deetz S. Discursive formations, strategised subordination and self-surveillance. In McKinlay A, Starkey K, editors. Foucault, management and organisation theory. London: Sage; 1998; p. 151-172.

27. Jarvis J. The voice of the Religion Education teacher in a context of religious diversity. Alternation Special Edition. 2009;3:157-176.

28. Allen L. From votes to dialogues: Clarifying the role of teachers' voices in schoo renewal. Phi Delta Kappan. 2004;86(4):318-321. https://doi.org/10.1177/ 003172170408600416

29. Hermans $\mathrm{H}$. The dialogical self: A process of positioning in space and time. In Gallagher $S$, editor. The Oxford handbook of the self. Oxford: Oxford University Press; 2011; p. 652-678.

30. Ipgrave J. Dialogue, citizenship and religious education. In: Jackson R, editor International perspectives on citizenship, education and religious diversity. London: RoutledgeFalmer; 2003; p. 147-168.

31. Roux C. Collaboration in teacher education through research in multicultura education. S Afr J Educ. 2007:21(3):503-509. https://doi.org/10.4314/sajhe. v21i3.25720
32. Ipgrave J. Identity and inter-religious understanding in Jewish schools in England. Br J Relig Educ. 2016;38(1):47-63. https://doi.org/10.1080/01416200.2014.984584

33. Gadamer H-G. Classical and philosophical hermeneutics. Theory Cult Soc. 2006;23(1):29-56. https://doi.org/10.1177/0263276406063228

34. MacIntyre A, Dunne J. Alasdair MacIntyre on education: In dialogue with Joseph Dunne. J Philos Educ. 2002;36(1):1-19. https://doi.org/10.1111/1467-9752.00256

35. Botha J, Du Preez P. Teaching-learning for democracy and human rights in the Life Orientation curriculum: experiential and dialogical learning methodologies. In $\mathrm{Nel} \mathrm{M}$, editor. Life orientation for South African teachers. Pretoria: Van Schaik; 2018; p. 147-161.

36. Abdool D, Drinkwater M. Guidelines to create a positive classroom climate for Religion Education: An empathetic approach. Scriptura. 2005;89:363-372. https://doi.org/10.7833/89-0-1023

37. Barton G, Garvis S. Theorizing compassion and empathy in educational contexts. What are compassion and empathy and why are they important? In: Barton G, Garvis S, editors. Compassion and empathy in educational contexts. Cham Palgrave MacMillan; 2019. p. 3-14.

38. Roux C. A social justice and human rights education project: A search for caring and safe spaces. In: Roux C, editor. Safe spaces: Human rights education in diverse contexts. Rotterdam: Sense Publishers; 2012; p. 29-50.

39. Du Preez P. A human rights-based curriculum for religious schools: The responsibilities of school leaders. In: Buchanan M, editor. Leadership \& religious schools: international perspectives and challenges. London: Bloomsbury; 2013; p. 53-67.

40. Redmond M. Safe space oddity: Revisiting critical pedagogy. J Teach Soc Work 2010;30(1):1-14. https://doi.org/10.1080/08841230903249729

41. Stengel S, Weems L. Questioning safe space: An introduction. Stud Philos Educ. 2010;29(6):505-507. https://doi.org/10.1007/s11217-010-9205-8

42. Samuel M, Stephens D. Critical dialogues with self: Developing teacher identities and roles - A case study of South African student teachers. Int J Educ Res. 2000;33:475-491. https://doi.org/10.1016/S0883-0355(00)00030-6 